\title{
Meaning and Try of Teaching Validity in Non-Government College
}

\author{
Y.Q.ZHAO \\ Changchun Architecture \& Civil Institute, Changchun, Jilin, China
}

\begin{abstract}
Non-government college run not for a long time. The students have a poor foundation, learning habits is weak. Then we need to update the concept of education, must putting students first. Change the traditional teaching philosophy, teaching methods and skills up to the conscious teaching mode. To improve the effectiveness of teach actually. To improve the effectiveness of teaching is the basic requirement of deepening the curriculum reform of private University, is the 'lifeline' of private university teaching.
\end{abstract} KEYWORD: Non-government colleges; educational idea; teaching mode; try; effectiveness; lifeline.

Higher education has developed from elite education to mass education. The Non-government College arises at the historic moment. From the overall situation of the 10 years of education, hade meet the needs of the training of professionals of social needs, and meet the basic requirements of the state on under graduate teaching, also to meet the needs of the young students learning desire. But, from the cultivation of "all-round development of talents", to adapt to the rapid development of the time, there is a big gap.

\section{EFFECTIVENESS IS THE LIFELINE PRIVATE OF PRIVATE UNIVERSITY TEACHING}

In the new century, science and technology change rapidly, the rapid development of the world economy, human society increasingly progress. Private university is faced with more urgent than key and ordinary institutions of higher learning and difficult development problems. In 2010, the Premier When said talks with 80 , after 90 college students on the Internet: Only first-class education to cultivate first-class talents, to build first-class national. As the feature of private the university students based on poor and learning habit of weak, we even more need to change us concept. Under the guidance of principle that teaching in accordance must orient students and student developmentoriented. To deepen reform of classroom teaching , Optimize the structure of teaching, Renewing teaching content, Improve teaching methods and must step onto a effectively path.
We think, to improve the effectiveness of teaching is the key to deepening the curriculum reform and the basic requirements. It is the lifeline of private university teaching. Then must be from the perspective of system and from the overall situation, change concrete the skills of teaching method become conscious teaching mode. Not only solve the problems what to teach and how to teach, more to solve the problem that learn what and how to learn. To improve the effectiveness of teach actually.

\section{THE FOUR TRY TO IMPROVE THE EFFECTIVENESS OF TEACHING}

\subsection{Carefully select content of courses}

According to the target of training applied talents in private university, In the basis of reasonable course system, Carefully select content of courses. Refinement each link in the teaching process, and construct new methods of teacher behavior. The interaction between teachers and students and teaching benefits teachers as well as students, then create of students' classroom learning atmosphere, promoting the coordinated development of intelligence factors and non intelligence factors. Excitation, promotion, maintenance of students' active learning, self learning, enable the students to obtain the efficiency and the effect of higher learning and progress.

After the project of talent fostering and the curriculum system was determined, the syllabus and the content select are important factors to decision 
the effectiveness of teaching. To meet the requirements of university undergraduate course, also to suit the requirements of training applied talents. According to the talents cultivation target and the market needs to determine the major course, that running the process backwards its content of courses of professional and specialized basic course. Adhere to the following three selection principle: First, must meet basic requirements for the undergraduate education by the Ministry of Education. Second, the main courses must meet the employment and exam needs for registered. Third, the other courses should be based on the needs to study main and curriculum courses. Based on many years of teaching practice, to comb the curriculum knowledge context, to understand its internal rules, to build the knowledge structure, gradually formed and refined the four principles. They are "highlight the emphasis and difficulty, but no loss knowledge system", "understand the truth and clear method", "typicality and pertinently" and "learn in order to practice" as on the basis of guiding to select course content and to teach.

Teachers should be showing the process of knowledge formation in classroom teaching, development context of subject thought and the thought method to solve problems. Public should pay attention to student life world, the reality of social development, modern science and technology, the actual production and book knowledge communication. For example, in material mechanics course teaching, In order to meet the requirements of safe and economic, always focus on the three aspects of the problem, which is "the strength, stiffness and stability of members". But, throughout follow a (first the external forces, then the internal forces, last the stress) basic ideas. In whole process of teaching strengthening the basic train of thought, transform miscellaneous into simple and clear, enable students to clear thinking and rule-based.

On this basis, public should solidify these effective strategies and practices they was proved by teaching practice under after the system exploration into teaching program and detailed into the teaching plan and the multimedia courseware.

\subsection{Optimize the teaching method}

The teaching design is effective or no, the key of classroom teaching is the learning based on the teaching, or is the teaching based on the study. From an "how to learn" perspective thinking about the problem, to carry on the teaching design but no from an "how to teach". What to teach, how to teach, which are determine according to the actual acceptable level of students. At the same time according to the training objectives for applied talents and educational philosophy of the school, gradually formed two ways, one is the practice teaching, another is theory teaching.

First, make full use of practical teaching base of school, teach in the laboratory and hands-on workshops, let improved the students' practical ability in practice. Second, follow the principle of cognition, we refined and tried out a basic method for teaching civil engineering mechanics courses in private university, it is "Five Rings Teaching Methods" [1]. Grasp five classroom teaching link, they are "Create engineering situations, to stimulate interest in learning; Inspire to think and associate to introduce the new knowledge naturally; deeply inquiry into the law, to find out the methods and steps"; to combined with engineering examples and understand the application methods; to summarize systematically and Incorporate them into the students' knowledge structure". That is to create a relaxed classroom atmosphere, to mobilize the initiative and enthusiasm of students in study, to guide the students to conduct in-depth thinking, Just as American educator Dewey said: "the process of education were to become real teachers and students to participate in, to "Become the interaction process of real cooperation".

The digital multimedia is today's most advanced form of audio and video to storage and transmission .Implementation of the above two kinds of teaching methods, people must give full play to the advantages of computer multimedia technology, Making multimedia courseware has interactive function and teacher's personal style is the effective carrier of teacher's knowledge, intelligence, emotion and thought.

\subsection{Improve the quality of the Humanities}

Teaching is the unity of teaching and learning process. But in the teaching process, some students do not necessarily in learn. Even they are learning, probably learn passively, inefficient learning. Zukav pointed out: "Teaching method once the students hit the emotion and will, once the students hit the emotion and will, touch students' spiritual needs, then this teaching method can play the highly effective role." Former Soviet educator Sue Home Linsky said: "Only touching students emotion, they can learn and master the knowledge". Thus, It is necessary to the teachers should try to do the student's good friend, speak to them with reason and compassion, try various devices to but don't be anxious for success, Guide students to self orientation, self-control, self motivation, while imparting knowledge. We have targeted use of leisure time before and after class and mainly to do four things.

(1)Recommend a Book: The famous writer Shi TieSheng wrote "I and the temple of earth". By watching "courseware", by their own make, with the 
help of the author's personality and works of the students on probation, especially the author's three most famous motto on the perception of life and death and ideal. (1)Now the death is a festival to be coming necessarily. So, there is no need to think. Need is how to live. (2)The ideal is not in order to achieve formerly. It is only in order to introduce the process. (3) The most important is not you are in what position, but you toward what direction.

(2) Donate towards three sentences. First, the French writer Sinner Kerr said: "In the process of the waiting universe is generated and changed, I'm just a extremely accidental existence. I am equal to zero when faced infinite. I'm the whole shoot when faced with own."

Second: "Some people say, 'Philosophy think about the life, the art attach to the life, the Religion transcend of life"".

Third: "I say: Society drama life. In the big social drama, everyone is the audience, but he also is the role."

Donate towards the above three sentences, the aim is to cause the students' thinking. When I presented the three sentences, Often calculate of a person finite life. Now, the other teachers in our institute also try to improve the quality of teaching by the way Improved the quality of the Humanities, and thy present the three sentences to their own students, too.

(3)Appreciate the three songs. A person with love in heart, there are songs In his heart, they are flowing surely. In Beijing Second Experimental Primary School teacher MaoZheng Hao said: "Without love there is no education". I often use the time between classes and after-school, I play or sing the songs in my heart for the person, who I eagerly looked forward to become a useful one. The three song is "Legend of the wooden fish stone", "I love you China" and "Here is a piece of warm land". Although they are of different styles but the song is beautiful and the words are fresh deeply moved by the people and stimulated. The teaching practice proves, these songs like the clear spring in the spring, It spread and nourish the heart of every student. It transfers an old teacher's affection, uplifting aspirations. It carry a heart which expect students to become a useful person, let students Progress andgrowth with the pleasure soul.

(4)Cultivate the students' scientific thinking method. Descartes said: "The most valuable knowledge is the knowledge about method." [2] As the former vice president of Shanghai University WeiChang Qian warned us of the: "We want the students to school mainly is to master a correct learning method, work method and thinking method that is the Methods of dialectical materialism. The courses or is specialty, or is nothing more than a carrier, through this carrier to train students to master this method." One is I am in the process of teaching, or answering time, pay attention to training students "ability of abstract thinking combined with image thinking closely". Two is, understanding the relationship between generality and individuality. Three is, refined and spread new innovation thinking method "related divergence, directional convergence, innovation to check at any time". Let the thinking method of "discard the dross and select the essential, discard the false and retain the true, from the outside to the inside, proceed from the one to the other" become more clearly, to form of knowledge structure that is scientific, conscious and able to associate. Then know how to think, how to do the right thing in the right way.

Teachers in the implementation of the above measures, casually but intentionally; to prepare, choose the time of implementation, in order to effect.

\section{THE IMPLEMENTATION EFFECT}

T Mr. Tao XingZhi said: "Teach is in order do not to teach". The development of humanistic quality and non intelligence factors, to stimulate students interest in learning, create a free learning environment, training students to innovative thinking, teach students how to learn. Not only to learn what the books, but to learn the knowledge outside the books especially. Now, in our school, the new atmosphere has already formed of optimistic, and work hard. By it, the students change own destiny, realize the lofty ideal. Most of the students completed the "want me to learn" into "I want to learn".

Human factors such as values, attitudes and methods, melting as a whole with the knowledge and skills, more easily penetrate into the hearts of students, realization of communication with students' emotion, exchange of ideas, collided in the soul and incentive ideal, guide the students to actively participate in learning, to improve classroom teaching effect. Facts improved, develop the humanistic view of students, to inspire the life power forward, it have twice the result with half the effort. One student wrote a poem to the teacher to express their gratitude to this kind of teaching initiatives. Many of the students copy "Pick up shells on the teaching ocean" wrote by my teaching experience for 37 years, and often read, drain power.

\section{TWO CONSIDERATIONS}

(1)As a teacher, careful design and implementation in course teaching, as an organic whole, Take Imparting knowledge and educating people as a organic whole or a system to think over. To optimize the teaching methods, teaching content, to develop 
the humanities quality and the cultivation of innovative thinking. Apply these four measures at same time, they can complement each other, complement each other, to maximize the benefit of education. This is an effective way to improve the effectiveness of teaching.

(2) In 2012 March in the government work report emphasized: "The first-class university should have the spirit of university". The first-class university should train the personnel with great ambition. In own teaching practice, teachers explore and implement effective teaching measure with the students love and desire, Is the need to establish a "university spirit and "The personnel with great ambition".

Education is the cornerstone of national rejuvenation. To improve the effectiveness of teaching must go through a longer time to complete. Our work is only a preliminary attempt. Take a heavy burden and embark on a long road. We will take the bull by the horns, continuously improve the overall level of personnel training quality and run school.

\section{REFERENCES}

[1] YuanQin Zhao, Mechanics Courses Forum Proceedings, Higher Education Pess, 2009.9, P81.

[2] Wang YanGen, Learning to Learn, Beijing, Education Press, 2003.8.

[3] The theory and practice of teaching mode innovation, Zuo Yang Ed, Jilin people's publishing press, In May 2002.

[4] The New Theory of teaching art, HongFeng Liu Ed. Military YiWen Press In December 1995.

[5] The Principle of Making Multimedia Courseware, YuanQin ZHAO, The Science and Technology of Zhonghua construction, 2012.10.

[6] The Research of construction and application of practice teaching base group of civil engineering of independent institute, YuanQin ZHAO, Jilin Education Science, 2008.5.

[7] Theoretical mechanics, YuanQin Zhao Ed. Wuhan university Press, In May 2014.

\section{AUTHOR'S BRIEF INTRODUCTION}

YuanQin Zhao, male, professor, born in 1945, vice president Civil engineering academe of Changchun Institute of Architecture. 